\title{
DAMPAK KONSUMSI KOPI PADA PENURUNAN KADAR GLUKOSA DARAH PENDERITA DIABETES MELLITUS TIPE 2
}

\author{
Riski Handiani Anwari \\ Fakultas Kedokteran, Universitas Lampung, Jl. Prof. DR. Ir. Sumatri Brojonegoro No.1, Gedong Meneng, \\ Kec. Rajabasa, Kota Bandar Lampung, Lampung, Indonesia 35145 \\ Riskihandiani@gmail.com (+6281281070726)
}

\begin{abstract}
ABSTRAK
Diabetes mellitus tipe 2 merupakan suatu penyakit yang ditandai dengan tingginya kadar glukosa darah. Kadar glukosa darah yang tinggi pada penderita diabetes mellitus tipe 2 akan meningkatkan risiko terjadinya komplikasi seperti stroke, ketoasidosis diabetik, retinopati, ulkus diabetik dan komplikasi lainnya. Salah satu pengobatan yang direkomendasikan untuk menurunkan kadar glukosa darah pada penderita diabetes mellitus tipe 2 adalah dengan mengkonsumsi kopi. Oleh karena itu, literature review ini ditulis dengan tujuan untuk melihat dampak konsumsi kopi pada penurunkan kadar glukosa darah penderita diabetes mellitus tipe 2 . Metode yang digunakan adalah metode literature review dari 33 artikel terpilih yang ditemukan pada database NCBI, PubMed, dan Google Scholar dengan kata kunci "diabetes mellitus tipe 2", "glukosa darah", dan "kopi" dari tahun 2002 hingga 2021 yang kemudian dianalisis sesuai dengan metode sistematik literature review. Dari beberapa penelitian yang sudah dilakukan, didapatkan hasil bahwa mengkonsumsi kopi dapat menurunkan kadar glukosa darah pada penderita diabetes mellitus tipe 2 .
\end{abstract}

Kata kunci: diabetes mellitus tipe 2; glukosa darah; kopi

\section{IMPACT OF COFFEE CONSUMPTION ON REDUCING BLOOD GLUCOSE LEVELS IN TYPE 2 DIABETES MELLITUS PATIENTS}

\begin{abstract}
Type 2 diabetes mellitus is a disease characterized by high blood glucose levels. High blood glucose levels in people with type 2 diabetes mellitus will increase the risk of complications such as stroke, diabetic ketoacidosis, retinopathy, diabetic ulcers, and other complications. One of the recommended treatments to reduce blood glucose levels in people with type 2 diabetes mellitus is to consume coffee. Therefore, this literature review was written with the aim of looking at the impact of coffee consumption on lowering blood glucose levels in patients with type 2 diabetes mellitus. The method used is the literature review method of 33 selected articles found in the NCBI, PubMed, and Google Scholar databases with the words Keywords "diabetes mellitus type 2", "blood glucose", and "coffee" from 2002 to 2021, which were then analyzed according to a systematic literature review method. From several studies that have been carried out, it is found that consuming coffee can reduce blood glucose levels in people with type 2 diabetes mellitus.
\end{abstract}

Keywords: blood glucose; coffee; type 2 diabetes mellitus

\section{PENDAHULUAN}

Diabetes mellitus adalah suatu penyakit kronik metabolik yang ditandai dengan kadar glukosa darah yang tinggi akibat adanya gangguan produksi insulin, gangguan kerja insulin atau keduanya (Petersmann et al., 2019). Berdasarkan penyebabnya, diabetes dapat diklasifikasikan menjadi 4 jenis yaitu diabetes mellitus tipe 1 , diabetes 
mellitus tipe 2, diabetes gestasional dan diabetes mellitus tipe lain. Diantara ke4 jenis diabetes tersebut, diabetes mellitus tipe 2 merupakan jenis diabetes yang paling sering dijumpai yaitu sekitar $90-95 \%$ dari total penderita diabetes mellitus (Power, 2019).

Diabetes mellitus merupakan suatu penyakit dengan tingkat pertumbuhan kasus tercepat di dunia (Cole \& Florez, 2020). Pada tahun 2014, jumlah penderita diabetes mellitus meningkat empat kali lipat dari 108 juta orang pada tahun 1980 menjadi 422 juta orang pada tahun 2014 hanya dalam waktu 34 tahun (WHO Global Report on Diabetes, 2016). Menurut data yang dikeluarkan oleh International Diabetes Federation, sekitar 463 juta orang di dunia dengan kelompok usia 20-79 tahun menderita diabetes mellitus pada tahun 2019 atau setara dengan angka prevalensi sekitar 9,3\% dari total penduduk dengan usia yang sama. Angka ini diprediksi akan terus meningkat menjadi 700 juta pada tahun 2045. Selain tingkat prevalensinya yang tinggi, tingkat mortalitas diabetes mellitus juga cukup tinggi. Pada tahun 2019, lebih dari 4 juta orang berusia 20-79 tahun meninggal dunia akibat diabetes mellitus (Atlas, 2019).

Indonesia sendiri menempati urutan ke7 dengan jumlah kasus diabetes mellitus pada kelompok usia 20-79 tahun terbanyak di dunia pada tahun 2019, yaitu sebanyak 10,7 juta orang. Angka ini diperkirakan akan terus meningkat menjadi 13,7 juta pada tahun 2030 (Atlas, 2019). Prevalensi diabetes mellitus di Indonesia pada tahun 2018 berdasarkan diagnosis dokter pada kelompok usia $\geq 15$ tahun mengalami kenaikan apabila dibandingkan dengan tahun 2013 menjadi 2\%. Selain itu, prevalensi diabetes mellitus berdasarkan hasil pemeriksaan gula darah pada tahun 2018 juga mengalami peningkatan menjadi $8,5 \%$. Angka ini menunjukan bahwa baru sekitar $25 \%$ penderita diabetes mellitus yang menyadari bahwa dirinya menderita diabetes mellitus (Kementrian kesehatan republik indonesia, 2020).

Penderita diabetes mellitus biasanya akan mengalami sindroma klinik berupa poliuria, polidipsia dan polifagia, disertai dengan adanya peningkatan kadar glukosa dalam darah (Power, 2019). Hiperglikemia atau tingginya kadar glukosa dalam darah merupakan kondisi yang biasanya terjadi pada pasien diabetes mellitus. Hal yang mendasari terjadinya hiperglikemia pada pasien diabetes mellitus adalah adanya defisiensi insulin baik secara relative maupun absolute. Keadaan hiperglikemia yang tidak terkontrol pada pasien diabetes mellitus akan menimbulkan berbagai kerusakan yang serius pada banyak sistem dalam tubuh terutama sistem saraf dan pembuluh darah (Yustisiani et al., 2013). Untuk mencegah terjadinya komplikasi lebih lanjut maka perlu dilakukan upaya tatalaksana baik itu tatalaksana farmakologi maupun non farmakologi (Subeki \& Muhartono, 2015).

Salah satu terapi alternatif yang direkomendasikan untuk pengobatan diabetes mellitus tipe 2 adalah dengan mengkonsumsi kopi secara rutin (Subeki \& Muhartono, 2015). Beberapa studi kohort di Amerika Serikat, Asia, dan Eropa telah menunjukkan bahwa mengkonsumsi kopi dapat menurunkan risiko penyakit diabetes mellitus tipe 2 (Alperet et al., 2020). Hal ini dikarenakan kopi mengandung berbagai senyawa kimia yang diduga dapat meningkatkan penyerapan glukosa dan 
metabolisme glukosa (Kempf et al., 2010).

Asam klorogenat merupakan salah satu kandungan kopi yang berperan penting dalam menurunkan kadar glukosa dalam darah. Asam klorogenat bekerja dengan cara menghambat translokasi glukosa-6 fosfat (Kobayashi et al., 2017). Selain asam klorogenat, senyawa lain pada kopi seperti kafestol, kahweol, trigonelin dan magnesium juga berperan penting dalam penurunan kadar glukosa dalam darah (Akash et al., 2014).

Tingginya prevalensi diabetes mellitus tipe 2 dan manfaat kandungan senyawa yang terdapat pada kopi terhadap kadar glukosa darah melatarbelakangi penulisan literature review ini. Literature review ini dibuat dengan tujuan untuk melihat dampak konsumsi kopi pada penurunan glukosa darah penderita diabetes mellitus tipe 2. Hal ini dapat digunakan sebagai pertimbangan pengelolaan pasien dibetes mellitus tipe 2 dalam mengendalikan kadar glukosa darah agar tidak menimbulkan komplikasi lebih lanjut.

\section{METODE}

Metode yang digunakan dalam penulisan artikel ini adalah studi literature review dari berbagai jurnal, baik jurnal nasional maupun internasional. Penelurusan awal literatur dilakukan melalui database NCBI, PubMed dan Google Scholar dengan kata kunci "diabetes mellitus tipe 2", "glukosa darah", dan "kopi". Ditemukan sekitar 87 artikel dari tahun 2002 hingga 2021 dengan kata kunci tersebut. Kemudian dari 87 artikel tersebut dipilih 33 artikel untuk dianalisis lebih lanjut. Artikel yang didapat kemudian dianalisis sesuai dengan metode sistematik literature review yaitu dengan cara diidentifikasi, dinilai dan diinterpretasikan semua temuan penelitian untuk menjawab pertanyaan penelitian (review question) dengan cara merangkum hasil penelitian (summarizing).

\section{HASIL}

Berdasarkan penelitian yang dilakukan oleh Prasetyo dan Sutanta pada tahun 2014, didapatkan hasil berupa adanya penurunan rata-rata kadar gula darah sewaktu dari 32 orang responden yang menderita diabetes mellitus tipe 2 sebesar 42,96875 mg/dl setelah mengkonsumsi kopi sebanyak 3 kali sehari selama 14 hari. Hasil ini menjelaskan adanya pengaruh konsumsi kopi terhadap kadar gula darah sewaktu pada penderita diabetes mellitus tipe 2 . Hal ini didukung dengan hasil uji statistik berupa $\mathrm{p}=0,000$ $(\mathrm{p}<0,05)$ yang menunjukkan adanya perbedaan nilai kadar gula darah sewaktu yang signifikan antara sebelum dan sesudah mengkonsumsi kopi pada penderita diabetes mellitus tipe 2 (Prasetyo \& Sutanta, 2015).

Hasil yang sama didapatkan pada penelitian yang dilakukan oleh Tjahjono dan Danang pada tahun 2014. Penelitian ini dilakukan pada 16 orang penderita diabetes mellitus tipe 2. Hasil penelitian ini menunjukkan adanya penurunan kadar glukosa darah setelah mengkonsumsi kopi secara teratur selama 1 minggu yaitu dari 239,65 $\mathrm{mg} / \mathrm{dl}$ menjadi 201,85 $\mathrm{mg} / \mathrm{dl}$. Uji Wilcoxon Signed Rank Test pada penelitian ini diperoleh nilai $\mathrm{p}=0,021$ $(\mathrm{p}<0,05)$ sehingga dapat dikatakan bahwa konsumsi kopi berpengaruh dalam menurunkan kadar glukosa darah pada pasien diabetes mellitus tipe 2 (Tjahjono \& Danang, 2014). 
Yustisiani et al, pada tahun 2013 juga melakukan penelitian yang serupa tetapi dengan sampel berupa tikus putih strain wistar yang menderita diabetes melitus tipe 2. Pada penelitian ini sampel dibagi kedalam 4 kelompok yaitu kelompok negatif, kelompok kontrol positif, kelompok yang diberikan kopi robusta dengan dosis $5,4 \mathrm{~mL} / 200 \mathrm{grBB} / \mathrm{hari}$ dan kelompok yang diberikan kopi robusta dengan dosis 10,8 mL/200 grBB/hari. Hasil penelitian didapatkan kelompok tikus yang diberikan kopi robusta dengan dosis 10,8 mL/200 grBB/hari memiliki kadar glukosa darah terendah dibandingkan dengan kelompok yang lain. Uji One way ANOVA pada tikus setelah pemberian kopi didapatkan hasil $\mathrm{p}=0,000(\mathrm{p}<0,05)$ yang artinya terdapat perbedaan bermakna antara pemberian kopi terhadap penurunan kadar glukosa darah tikus putih strain wistar yang menderita diabetes mellitus tipe 2. Uji korelasi juga dilakukan pada penelitian ini, dimana didapatkan hasi berupa $\mathrm{p}=0,000(\mathrm{p}<0,05)$ dengan nilai pearson correlation $=-0,978$, hasil ini menunjukkan adanya korelasi berbanding terbalik yang berarti semakin tinggi dosis kopi akan menyebabkan semakin besar penurunan glukosa darah (Yustisiani et al., 2013).

Penelitian Lee et al, pada tahun 2016, didapatkan hasil bahwa konsumsi kopi dapat menghambat perkembangan terjadinya diabetes mellitus tipe 2 . Penelitian ini dilakukan pada 3497 pasien pre-diabetik selama 2 tahun. Dari penelitian ini didapatkan hasil bahwa pasien pre-diabetik yang menkonsumsi kopi hitam minimal 3 kali per hari memiliki perkembangan terjadinya diabetes mellitus tipe 2 yang sangat lambat dengan nilai $\mathrm{p}=0,036(\mathrm{p}<0,05)$ (Lee et al., 2016).

\section{PEMBAHASAN}

Diabetes mellitus merupakan penyakit metabolik yang sangat sering terjadi di dunia. Berdasarkan klasifikasi American Diabetes Association, terdapat 4 jenis diabetes mellitus yaitu diabetes mellitus tipe 1 , diabetes mellitus tipe 2, diabetes mellitus tipe lain dan diabetes gestasional (Kerner \& Brückel, 2014). Diabetes mellitus tipe 1 merupakan diabetes mellitus yang disebabkan karena adanya destruksi pada sel beta pankreas sehingga tidak dapat memproduksi insulin. Diabetes mellitus tipe 1 sering juga disebut dengan insulin-dependent diabetes mellitus (Morran et al., 2015). Berbeda dengan diabetes mellitus tipe 1 , diabetes mellitus tipe 2 disebut sebagai noninsulin dependent diabetes mellitus dan biasanya lebih sering terjadi pada orang dewasa, sedangkan diabetes mellitus gestasional biasanya terjadi pada $5-15 \%$ wanita hamil. Jenis diabetes mellitus yang terakhir yaitu diabetes meatus tipe lain. Diabetes mellitus tipe ini dapat disebabkan oleh berbagai hal contonya obstruksi pankreas, operasi dan transplantasi organ (Alam et al., 2021).

Dari ke-4 jenis diabetes mellitus, diabetes mellitus tipe 2 merupakan jenis diabetes mellitus yang paling sering terjadi. Sekitar 90-95\% penderita diabetes mellitus dilaporkan menderita diabetes mellitus jenis ini. Diabetes mellitus tipe 2 merupakan penyakit yang ditandai dengan terjadinya peningkatan kadar glukosa dalam darah akibat berkurangnya sekresi insulin atau karena resistensi insulin (Power, 2019).

Kejadian diabetes mellitus tipe 2 dipengaruhi oleh beberapa faktor yaitu faktor genenik, lingkungan dan gaya hidup (Chen et al., 2012). Beberapa studi menyatakan bahwa seseorang 
yang memiliki riwayat keluarga dengan diabetes mellitus tipe 2 akan berisiko lebih besar terkana diabetes mellitus tipe 2 dibandingkan dengan yang tidak memiliki riwayat keluarga dengan penderita diabetes mellitus tipe 2 (Rother, 2007). Lingkungan dan gaya hidup juga sangat berpengaruh terhadap kejadian diabetes mellitus tipe 2, dimana orang yang menerapkan sedentary lifestyle, merokok, obesitas dan mengkonsumsi alkohol memiliki risiko yang tinggi terkena diabetes mellitus tipe 2 (Olokoba et al., 2012).

Manifestasi klinik yang biasa muncul pada penderita diabetes mellitus tipe 2 yaitu poliuria, polidipsi, polifagia, penurunan berat badan dan disertai dengan peningkatan kadar gula darah atau hiperglikemia (kadar gula darah sewaktu $\geq 200 \mathrm{mg} / \mathrm{dl}$ atau gula darah postprandial $\geq 200 \mathrm{mg} / \mathrm{dl}$ atau gula darah puasa $\geq 126 \mathrm{mg} / \mathrm{dl}$ ) (Power, 2019).

Pengaturan glukosa darah dalam tubuh dilakukan dengan bantuan hormon insulin. Hormon insulin merupakan horman yang berasal dari sel beta pankreas. Pada pasien diabetes mellitus tipe 2 , sel beta pankreas tetap dapat memproduksi hormon insulin tetapi terjadi penurunan jumlah hormon insulin yang disekresikan di dalam tubuh. Berkurangnya jumlah insulin dalam tubuh akan menyebabkan proses pengaturan glukosa dalam darah menjadi terganggu sehingga terjadi hiperglikemia. Tingginya kadar glukosa darah pada pasien diabetes mellitus tipe 2 perlu dikontrol karena apabila tidak terkontrol maka keadaan ini dapat memperburuk manifestasi klinik yang muncul pada pasien (Tjahjono \& Danang, 2014).
Diabetes mellitus tipe 2 yang tidak terkontrol dengan baik akan menimbulkan berbagai macam komplikasi dalam tubuh. Komplikasi yang dapat muncul pada pasien diabetes mellitus dibagi menjadi dua kelompok, yaitu komplikasi akut dan komplikasi kronik. Contoh komplikasi akut dari diabetes mellitus yaitu hipoglikemia, ketoasidosis diabetik dan asidosis laktat. Sedangkan contoh komplikasi kronik dari diabetes mellitus yaitu komplikasi vaskuler seperti stroke dan retinopati, komplikasi neuropati seperti impotensi, kompikasi pada kulit dan campuran vascular neuropati yaitu ulkus kaki. Untuk mencegah terjadinya komplikasi akibat diabetes mellitus, maka perlu dilakukan tatalaksana yang sesuai baik itu tatalaksana farmakologi maupun non farmokologi (PERKENI, 2011).

Kopi merupakan salah satu pengobatan alternatif yang dapat digunakan untuk menangani kasus diabetes mellitus tipe 2. Beberapa kandungan senyawa yang ada di dalam kopi diduga dapat menurunkan kadar glukosa darah pada penderita diabetes mellitus tipe 2 (Prasetyo \& Sutanta, 2015). Hasil penelitian $\mathrm{Wu}$ et al, pada tahun 2015, menunjukkan bahwa kandungan asam klorogenat pada kopi dapat menurunkan kadar glukosa darah dengan cara mencegah terjadinya kegagalan sel beta pankreas dalam memproduksi insulin (Subeki \& Muhartono, 2015).

Kopi merupakan salah satu minuman yang banyak dikonsumsi oleh masyarakat di seluruh dunia (Kim et al., 2019). Kopi mengandung berbagai senyawa kimia seperti kafein, asam klorogenat, lemak, karbohidrat, kafestol, kahweol, tanin, asam amino, asam organik, trigonelin, oksalat, mineral dan senyawa lainnya. Senyawasenyawa yang terkandung dalam kopi 
dapat memberikan berbagai efek pada tubuh manusia, baik itu efek negatif maupun efek positif (Higdon \& Frei, 2006). Beberapa efek negatif yang mungkin muncul akibat mengkonsumsi kopi yaitu insomnia, mual, muntah, sakit kepala, heartburn, anxiety dan juga gastritis. Sedangkan efek positif dari mengkonsumsi kopi yaitu dapat menurunkan kadar glukosa darah (Maulidia \& Jatmiko, 2021).

Asam klorogenat adalah suatu senyawa fenolik utama di dalam kopi (5-12g/100 $\mathrm{mg}$ ) yang terbentuk dari esterifikasi asam kuinat dan asam sinamat tertentu seperti kafein, asam ferulat, dan pcoumaric (Farah \& Donangelo, 2006). Asam klorogenat merupakan suatu senyawa antioksidan yang dikenal berperan penting dalam mencegah berbagai penyakit yang berhubungan dengan stress oksidatif dan juga dikenal sebagai antidiabetes. Asam klorogenat memiliki efek antagonis terhadap transfer glukosa (Johnston et al., 2003). Asam klorogenat dapat membantu proses regulasi kadar glukosa darah dengan cara menghambat absorbsi glukosa instestinal dan meningkatkan sensitivitas insulin (Lee at al., 2016). Asam klorogenat akan menghambat aktivitas translokasi glukosa-6 fosfat. Terhambatnya proses ini menyebabkan penyerapan glukosa pada saluran gastrointestinal tertunda yang kemudian akan merangrang sekresi dari glucagonlike peptide 1 (GLP-1). Meningkatnya plasma glucagon-like peptide 1 (GLP-1) akan menyebabkan sel beta penkreas meningkatkan sekresi insulin dan menurunkan sekresi glukagon sehingga akan terjadi penurunan kadar glukosa darah (Kobayashi et al., 2017).

Selain asam klorogenat, senyawa lain pada kopi seperti kafestol, kahweol, trigonelin dan magnesium juga berperan dalam membantu proses regulasi kadar glukosa darah. Kafestol dan kahweol merupakan diterpanoid alami yang berada pada biji kopi (van Cruchten et al., 2010). Selain dikenal akan efeknya dalam meingkatkan serum lipid, hasil eksperimen in vitro dan in vivo telah menunjukkan bahwa kafestol dan kahweol berfungsi sebagai antiinflamasi, antiosteoklastogenesis hepatoprotektif, antikanker dan antidiabetes (Ren et al., 2019). Kafestol dan kahweol berperan dalam membantu memberikan sinyal PPAR $\gamma$ (Peroxisome proliferator-activated receptors gamma). PPAR $\gamma$ berfungsi sebagai reseptor ligan dan merupakan faktor transkripsi gen yang mempengaruhi fungsi insulin atau berperan dalam proses regulasi insulin (Ranheim \& Halvorsen, 2005).

Magnesium merupakan komponen lain dari kopi yang dapat membantu proses regulasi kadar glukosa darah. Magnesium merupakan mikronutrien yang dapat meningkatkan fungsi sel beta pankreas. Beberapa studi menunjukkan bahwa meningkatnya kadar eritrosit magnesium akibat mengkonsumsi kopi berkorelasi dengan peningkatan sekresi insulin (Gao et al., 2018).

Kopi juga mengandung senyawa bernama trigonelin. Trigonelin merupakan alkaloid yang berpotensi sebagai antidiabetes dan ditemukan dalam jumlah yang cukup besar dalam kopi (Folwarczna et al., 2016). Trigonelin memiliki cara kerja yang sama seperti asam klorogenat yaitu menghambat proses absorbsi glukosa intersinal sehingga dapat menurunkan kadar glukosa darah (Ding et al., 2014). 


\section{SIMPULAN}

Konsumsi kopi dapat menurunkan kadar glukosa darah pada penderita diabetes mellitus tipe 2. Hal ini dikarenakan kopi mengandung senyawa berupa asam klorogenat, kafestol, kahweol, magnesium dan trigonelin yang dapat membantu regulasi penurunan kadar glukosa darah.

\section{DAFTAR PUSTAKA}

Akash, M. S. H., Rehman, K., \& Chen, S. (2014). Effects of coffee on type 2 diabetes mellitus. In Nutrition (Vol. 30, Issues 7-8).

https://doi.org/10.1016/j.nut.2013.11.02 $\underline{0}$

Alam, S., Hasan, M. K., Neaz, S., Hussain, N., Hossain, M. F., \& Rahman, T. (2021). Diabetes Mellitus: Insights from Epidemiology, Biochemistry, Risk Factors, Diagnosis, Complications and Comprehensive Management. Diabetology, 2(2), 36-50. https://doi.org/10.3390/diabetolog y2020004

Alperet, D. J., Rebello, S. A., Khoo, E. Y. H., Tay, Z., Seah, S. S. Y., Tai, B. C., Tai, E. S., Emady-Azar, S., Chou, C. J., Darimont, C., \& Van Dam, R. M. (2020). The effect of coffee consumption on insulin sensitivity and other biological risk factors for type 2 diabetes: A randomized placebo-controlled trial. American Journal of Clinical Nutrition, 111(2).

https://doi.org/10.1093/ajen/nqz306

Atlas, I. D. F. D. (2019). Internatonal Diabetes Federation. In The Lancet (Vol. 266, Issue 6881). https://doi.org/10.1016/S0140$\underline{\text { 6736(55)92135-8 }}$
Chen, L., Magliano, D. J., \& Zimmet, P. Z. (2012). The worldwide epidemiology of type 2 diabetes mellitus - Present and future perspectives. In Nature Reviews Endocrinology (Vol. 8, Issue 4). https://doi.org/10.1038/nrendo.20 $\underline{11.183}$

Cole, J. B., \& Florez, J. C. (2020). Genetics of diabetes mellitus and diabetes complications. In Nature Reviews Nephrology (Vol. 16, Issue 7).

https://doi.org/10.1038/s41581-020$\underline{0278-5}$

Ding, M., Bhupathiraju, S. N., Chen, M., Van Dam, R. M., \& Hu, F. B. (2014). Caffeinated and decaffeinated coffee consumption and risk of type 2 diabetes: A systematicreview and a doseresponse meta-analysis. Diabetes Care, 37(2), 569-586.

https://doi.org/10.2337/dc13-1203

Farah, A., \& Donangelo, C. M. (2006). Phenolic compounds in coffee. Brazilian Journal of Plant Physiology, 18(1), 23-36. https://doi.org/10.1590/S1677$\underline{04202006000100003}$

Folwarczna, J., Janas, A., Pytlik, M., Cegieła, U., Śliwinśki, L., Krivošíková, Z., Štefíková, K., \& Gajdoš, M. (2016). Effects of trigonelline, an alkaloid present in coffee, on diabetes-induced disorders in the rat skeletal system. Nutrients, 8(3).

\section{https://doi.org/10.3390/nu8030133}

Gao, F., Zhang, Y., Ge, S., Lu, H., Chen, R., Fang, P., Shen, Y., Wang, C., \& Jia, W. (2018). 
Coffee consumption is positively related to insulin secretion in the Shanghai High-Risk Diabetic Screen (SHiDS) Study. Nutrition and Metabolism, 15(1).

https://doi.org/10.1186/s12986-018$\underline{0321-8}$

Higdon, J. V., \& Frei, B. (2006). Coffee and health: A review of recent human research. Critical Reviews in Food Science and Nutrition, 46(2).

https://doi.org/10.1080/1040839050040 $\underline{0009}$

Johnston, K. L., Clifford, M. N., \& Morgan, L. M. (2003). Coffee acutely modifies gastrointestinal hormone secretion and glucose tolerance in humans: Glycemic effects of chlorogenic acid and caffeine. American Journal of Clinical Nutrition, 78(4). https://doi.org/10.1093/ajcn/78.4. $\underline{728}$

Kementrian kesehatan republik indonesia. (2020). Tetap Produktif, Cegah Dan Atasi Diabetes Mellitus. In pusat data dan informasi kementrian kesehatan RI.

Kempf, K., Herder, C., Erlund, I., Kolb, H., Martin, S., Carstensen, M., Koenig, W., Sundvall, J., Bidel, S., Kuha, S., \& Tuomilehto, J. (2010). Effects of coffee consumption on subclinical inflammation and other risk factors for type 2 diabetes: A clinical trial. American Journal of Clinical Nutrition, 91(4).

https://doi.org/10.3945/ajen.2009.28548

Kerner, W., \& Brückel, J. (2014).
Definition, classification and diagnosis of diabetes mellitus. In Experimental and Clinical Endocrinology and Diabetes (Vol. 122, Issue 7).

https://doi.org/10.1055/s-0034-1366278

Kim, Y., Je, Y., \& Giovannucci, E. (2019). Coffee consumption and all-cause and cause-specific mortality: a meta-analysis by potential modifiers. European Journal of Epidemiology, 34(8). https://doi.org/10.1007/s10654019-00524-3

Kobayashi, M., Kurata, T., Hamana, Y., Hiramitsu, M., Inoue, T., Murai, A., \& Horio, F. (2017). Coffee ingestion

suppresses hyperglycemia in streptozotocininduced diabetic mice. Journal of Nutritional Science and Vitaminology, 63(3), 200-207. https://doi.org/10.3177/jnsv.63.20 $\underline{0}$

Lee, J. H., Oh, M. K., Lim, J. T., Kim, H. G., \& Lee, W. J. (2016). Effect of coffee consumption on the progression of type 2 diabetes mellitus among prediabetic individuals. Korean Journal of Family Medicine, 37(1). https://doi.org/10.4082/kjfm.2016. $\underline{37.1 .7}$

Maulidia, A., \& Jatmiko, S. W. (2021). Pengaruh Kopi terhadap Parameter Darah pada Tikus Putih Galur Wistar Diabetik yang Diinduksi Aloksan. Jurnal Kedokteran Dan Kesehatan, 17(1).

https://jurnal.umj.ac.id/index.php/JKK

Morran, M. P., Vonberg, A., Khadra, A., \& Pietropaolo, M. (2015). 
Immunogenetics of type 1 diabetes mellitus. In Molecular Aspects of Medicine (Vol. 42).

https://doi.org/10.1016/j.mam.2014.12.0 $\underline{04}$

Olokoba, A. B., Obateru, O. A., \& Olokoba, L. B. (2012). Type 2 diabetes mellitus: A review of current trends. In Oman Medical Journal (Vol. 27, Issue 4). https://doi.org/10.5001/omj.2012. $\underline{68}$

PERKENI. (2011). Konsensus Diabetes Mellitus. Perkeni, 16(1994), 1-27.

Petersmann, A., Müller-Wieland, D., Müller, U. A., Landgraf, R., Nauck, M., Freckmann, G., Heinemann, L., \& Schleicher, E. (2019). Definition, Classification and Diagnosis of Diabetes Mellitus. Experimental and Clinical Endocrinology and Diabetes, 127.

https://doi.org/10.1055/a-1018-9078

Power, D. (2019). Standards of medical care in diabetes: Response to position statement of the American Diabetes Association [20]. Diabetes Care, 29(2), 476. https://doi.org/10.2337/diacare.29. 02.06.dc05-1593

Prasetyo, A., \& Sutanta. (2015). Pengaruh Konsumsi Seduhan Bubuk Biji Kopi Terhadap Kadar Gula Darah Sewaktu Pada Penderita Diabetes. Jurnal Kesehatan Madani Medika, 6(1), 14-20.

Ranheim, T., \& Halvorsen, B. (2005). Coffee consumption and human health - Beneficial or detrimental? - Mechanisms for effects of coffee consumption on different risk factors for cardiovascular disease and type 2 diabetes mellitus. In Molecular Nutrition and Food Research (Vol. 49, Issue 3). https://doi.org/10.1002/mnfr.2004 $\underline{00109}$

Ren, Y., Wang, C., Xu, J., \& Wang, S. (2019). Cafestol and kahweol: A review on their bioactivities and pharmacological properties. In International Journal of Molecular Sciences (Vol. 20, Issue 17). https://doi.org/10.3390/ijms20174 $\underline{238}$

Rother, K. I. (2007). Diabetes Treatment - Bridging the Divide. New England Journal of Medicine, 356(15). https://doi.org/10.1056/nejmp078 $\underline{030}$

Subeki, \& Muhartono. (2015). Pengaruh Pemberian Infusa Kopi dalam Menurunkan Kadar Glukosa Darah Mencit yang Diinduksi Aloksan The Effect of Coffee Infusion in Lowering Blood Glucose Level in Mice Induced by Alloxan. Juke Unila, 5(9), 1-8.

Tjahjono, H., \& Danang, E. (2019). Pengaruh terapi kopi terhadap kadar gula darah acak pada pasien diabetes militus tipe 2 di desa waru beron rt. 06 rw. 02 balongbendo sidoarjo. Jurnal keperawatan, 3(2), 8

http://jurnal.stikeswilliambooth.ac.id/in dex.php/d3kep/article/view/7

van Cruchten, S. T. J., de Haan, L. H. J., Mulder, P. P. J., Kunne, C., Boekschoten, M. V., Katan, M. B., Aarts, J. M. M. J. G., \& Witkamp, R. F. (2010). The role 
of epoxidation and electrophileresponsive element-regulated gene transcription in the potentially beneficial and harmful effects of the coffee components cafestol and kahweol. Journal of Nutritional Biochemistry, 21(8). https://doi.org/10.1016/j.jnutbio.2 $\underline{009.05 .001}$

WHO Global Report on Diabetes. (2016). Global Report on Diabetes. Isbn, 978, 6-86.

https://sci-

hub.si/https://apps.who.int/iris/han dle/10665/204874\%0Ahttps://app s.who.int/iris/bitstream/handle/10 665/204874/WHO_NMH_NVI_1 6.3_eng.pdf?sequence $=1 \% 0$ Ahttp: //www.who.int/about/licensing/co pyright_form/index.html\%0Ahttp: //www.who.int/about/licens

Yustisiani, A., Andari, D., \& . I. (2013). Pengaruh Pemberian Kopi Terhadap Penurunan Kadar Glukosa Darah Pada Tikus Putih Strain Wistar Diabetes Mellitus Tipe 2. Saintika Medika, 9(1), 38. https://doi.org/10.22219/sm.v9i1. $\underline{4124}$ 